\title{
Manfacture of Al-B4c Metal Matrix Composites Via Stir Casting Methode
}

\author{
Sathiyaraj. S, S. Kalyankumar, Mohammed Fayis, N. Ronald Jaison, Rony Samraj
}

\begin{abstract}
Aluminum alloys are widely used in the aerospace and car industries due to their low density and suitable mechanical housing, excellent corrosion resistance and wear, and the low thermal coefficient of expansion compared to conventional metals and alloys. Exceptional mechanical residency of those alloys and the relatively low production value lead to a candidate that is very attractive for the diffusion of applications, from scientific and technical point of view. Manufacturing of aluminum alloy based totally casting composite with the aid of stir casting is one of the most within your budget techniques of processing MMC. The primary goal of this paper is to make aluminum metallic Matrix composite with different sythesis of fortification garbage of Boron Carbide Via utilizing mix throwing approach and Hardness of the Al-B4C MMCs measured via Vickers hardness method.
\end{abstract}

Keywords : Composite, steel Matrix Composite, Stir casting and Aluminium metallic Matrix Composite.

\section{INTRODUCTION}

A composite material is a fabric along with two or greater bodily and/or chemically distinct stages. The composite normally has advanced characteristics than those of every of Person additives. Usually the reinforcing aspect is sent inside the continuous or matrix element. When the matrix is steel, the composite is called a metallic-matrix composite (MMC).In MMCs, the reinforcement commonly takes the form of debris, whiskers, quick fibers, or non-stop fibers [1].

The need for contemporary development of advanced engineering materials trends for various engineering applications is now growing. The metallic matrix composite is one of the most reliable supply to meet such demands.

Revised Manuscript Received on December 30, 2019.

* Correspondence Author

Sathiyaraj.S*, ,Assistant Professor Mechanical Department, AarupadaiVeedu Institute Of Technology, Vinayaka Mission's Research Foundation, Deemed To Be University. Having 8 years of experience. Life member in ISTE and ENFUSE.

S.Kalyanakumar, Assistant Professor Mechanical Department, Aarupadai Veedu Institute of Technology, Vinayaka Mission's Research Foundation, Deemed To Be University. kalyanakumar@avit.ac.in.

Mohammed Fayis, UG Student, Mechanical Department, Aarupadai Veedu Institute of Technology, Vinayaka Mission's Research Foundation, Deemed To Be University.

N,Ronald Jaison, UG Student, Mechanical Department, Aarupadai Veedu Institute of Technology, Vinayaka Mission's Research Foundation, Deemed To Be University

Rony Samraj ,UG Student, Mechanical Department, Aarupadai Veedu Institute of Technology, Vinayaka Mission's Research Foundation, Deemed To Be University

(c) The Authors. Published by Blue Eyes Intelligence Engineering and Sciences Publication (BEIESP). This is an open access article under the CC BY-NC-ND license (http://creativecommons.org/licenses/by-nc-nd/4.0/)
Mixed material is one of the reliable answers to such a need. In composites, the ingredients are mixed to allow for greater use in their designated fabric while reducing the effects of their defects to a point [2]. Simple periodic compounds may indicate combinations of two or more cloths, which can

improve homes. But in the recent years, the development of commodities has shifted from monolithic to composite materials to compensate for the global preference for reduced overall weight in low-weight, low-cost, exceptional and structural materials. Driving pressure for the usage of AMMCs in areas of automobile industries and aerospace consist of economic performance, and overall performance surroundings all blessings.

\section{OBJECTIVES OF THE PROJECT}

The objectives of the task are:

* The primary objective of this paper is to fabricate Al-B4C steel Matrix composite with various composition (three. Five\%, 7.Zero\% and 10\%) of reinforcement debris of Boron Carbide by the usage of stir casting technique.

* The second one goal is hardness of the Al-B4C MMCs measured by means of Vickers hardness technique.

\section{PROPOSED SYSTEM}

\section{Aluminium 6061}

The aluminum alloy 6000, 7000 and 2000series are used to create car components. Check out the PAMC Below Matrix fabric of Aluminum Alloy Al6061, whose chemical composition and properties are shown in Table 1 and 2. One advantage of using aluminum as a matrix material is that the casting technology is well established, and many of the benefits of using aluminum as a matrix fabric have been linked to the generation of molding, and the most important is the mile lightweight material. Some of the hazards associated with aluminiums are given, including bonding are more tough than metal, low energy compared to steel and rate is $200 \%$ than metallic. But using proper reinforcement and treatment energy can be multiplied to desired stage. Aluminium 6061 matrix as shown in Fig 1.

Table1 Chemical composition of Al (6061)

\begin{tabular}{|l|l|l|l|l|l|l|l|l|}
\hline $\mathrm{Si}$ & $\mathrm{Fe}$ & $\mathrm{Cu}$ & $\mathrm{Mn}$ & $\mathrm{Mg}$ & $\mathrm{Cr}$ & $\mathrm{Zn}$ & $\mathrm{Ti}$ & $\mathrm{Al}$ \\
\hline
\end{tabular}

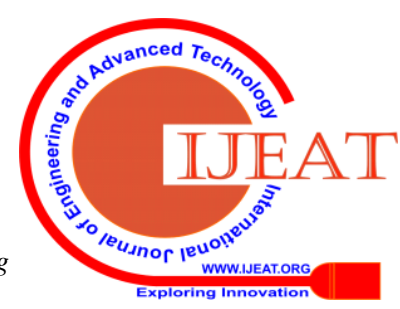




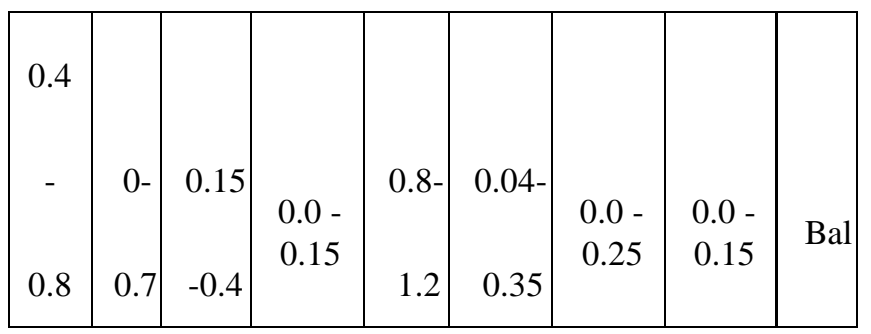

Table 2 Properties of Al (6061)

\begin{tabular}{|c|l|c|}
\hline S. No. & Melting Point & Approx $580^{\circ} \mathrm{C}$ \\
\hline 1 & Modulus of Elasticity & $70-80 \mathrm{GPa}$ \\
\hline 2 & Poisson's Ratio & 0.33 \\
\hline 3 & Density & $2.7 \mathrm{~g} / \mathrm{cm}^{3}$ \\
\hline 4 & Thermal Conductivity & $173 \mathrm{~W} / \mathrm{Mk}$ \\
\hline
\end{tabular}

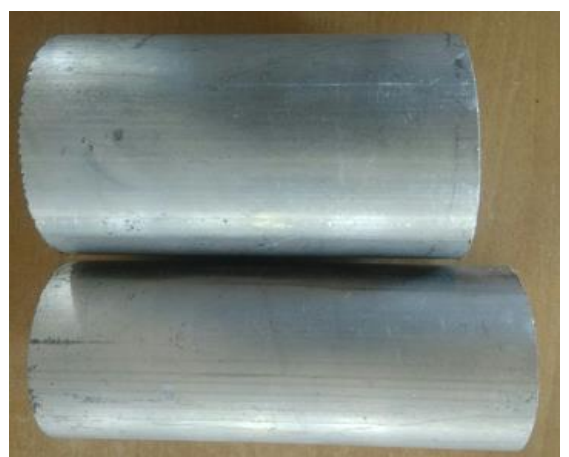

Fig 1: Aluminium 6061 Matrix

\section{Boron Carbide}

Boron Carbide is one of the hardest substances regarded, ranking $1 /$ three in the back of diamond and cubic boron nitride. It's miles the toughest cloth produced in tonnage quantities. Boron carbide powder is specifically produced by reacting carbon with $\mathrm{B} 2 \mathrm{O} 3$ in an electric powered arc furnace, via carbothermal discount or by fuel segment reactions. For business use B4C powders generally need to be milled and purified to do away with steel impurities. Boron carbide powder as shown in Fig 3. Its chemical composition and properties are shown in Table 3 and 4.The important things of boron carbide are:

* excessive hardness

* precise chemical resistance

* desirable nuclear homes

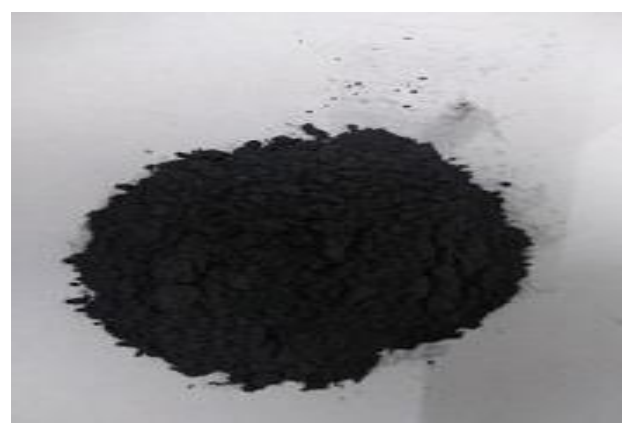

Fig 2 Boron Carbide Powder

Table 3 Chemical Composition of Boron Carbide

\begin{tabular}{|c|c|c|c|c|c|c|}
\hline Elements & $\mathrm{B}+\mathrm{C}$ & $\begin{array}{c}\mathrm{B} \\
\mathrm{Min}\end{array}$ & $\begin{array}{c}\mathrm{C} \\
\max \end{array}$ & $\mathrm{B}_{2} \mathrm{O}_{3}$ & $\mathrm{Fe}$ & $\mathrm{Si}$ \\
\hline Percentage & $\begin{array}{c}94-98 \\
5\end{array}$ & $74-79$ & $17-24$ & $\begin{array}{c}0.1-1 . \\
0\end{array}$ & $\begin{array}{c}0.2-0 . \\
5\end{array}$ & $\begin{array}{c}0.1-0 . \\
3\end{array}$ \\
\hline
\end{tabular}

Table 4 Properties of Boron Carbide

\begin{tabular}{|c|c|c|}
\hline Sr. No. & Melting Point & $2450^{\circ} \mathrm{C}$ \\
\hline 1 & Hardness $\left(\mathrm{Kg} / \mathrm{mm}^{2}\right)$ & 2750 \\
\hline 2 & Density $\left(\mathrm{g} / \mathrm{cm}^{3}\right)$ & 2.52 \\
\hline 3 & Coefficient of thermal expansion & $4.5\left(10^{-6} / \mathrm{K}\right)$ \\
\hline 4 & Fracture toughness & $3.5 \mathrm{MPa}$ \\
\hline 5 & Poisson's Ratio & 0.18 \\
\hline 6 & Colour & Black or Dark Gray \\
\hline
\end{tabular}

\section{PRODUCTION TECHNIQUE}

Stir casting a number of the kind of production methods available for metallic matrix composites (MMCs), stir casting gadget is normally widespread as a specially promising route, currently practiced commercially. Its gain lies in its simplicity, flexibility and applicability to big amount manufacturing. The first stirring device is best done with the help of the motor with the gearbox and the lightweight steel stirrer. All the melting is finished in a kiln burned with a graphite crusher oil furnace. The bars of aluminum 6061 were preheated at $1000^{\circ} \mathrm{C}$ for three to four hours before the silicon carbide particles were melting and combining. Heat up to 500 degrees.

The furnace temperature was first raised above the liquid in order to melt the alloy scrap and then cooled completely under the liquid to preserve the emulsion in a semi-stable nation. At this stage the preheated Boron Carbide particles have been added and blended thru stir casting setup. After adequate manual mixing is complete, The mixed broth is reheated to a completely liquid state after which computerized mechanical mixing modified into finished for approximately 10 mins at a regular stirring price of seven hundred rpm. Within the very last mixing system, the furnace temperature modified into controlled within $760^{\circ} \mathrm{C}$. Pouring of the composite slurry has been accomplished inside the die mold prepared in line with the dimensions $(100 \mathrm{~mm} \times 100 \mathrm{~mm}$ $\mathrm{x} 14 \mathrm{~mm})$. 
The essential experimental setup used here is stir casting and squeeze casting installation. Stir casting technique is a exceptionally low fee liquid processing gift to provide MMC and for this reason, this processing approach were applied on this. Fig 3 to 5 shows Stir casting setup used on this examine except being easy, flexible, and attractive, in comparison with other techniques; it additionally permits very massive period components to be fabricated Stir casting direction additionally guarantees that undamaged reinforcement substances are attained. Also fabricates Al-B4C MMCs specimen as proven in determine four.Three. The various compositions of samples are confirmed in Table 5.

Table 5 Compositions of samples

Sample of weight $=1250$ Grams

\begin{tabular}{|c|c|c|c|}
\hline $\begin{array}{c}\text { Sample } \\
\text { No }\end{array}$ & $\begin{array}{c}\text { Aluminium } \\
\text { (Grams) }\end{array}$ & $\begin{array}{c}\text { Boron } \\
\text { Carbide(Grams) }\end{array}$ & Remarks \\
\hline 1 & 1206.25 & 43.75 & Al-3.5\%B4C \\
\hline 2 & 1162.50 & 87.50 & Al-7.0\%B4C \\
\hline 3 & 1118.75 & 131.25 & Al-10.5\%B4C \\
\hline
\end{tabular}

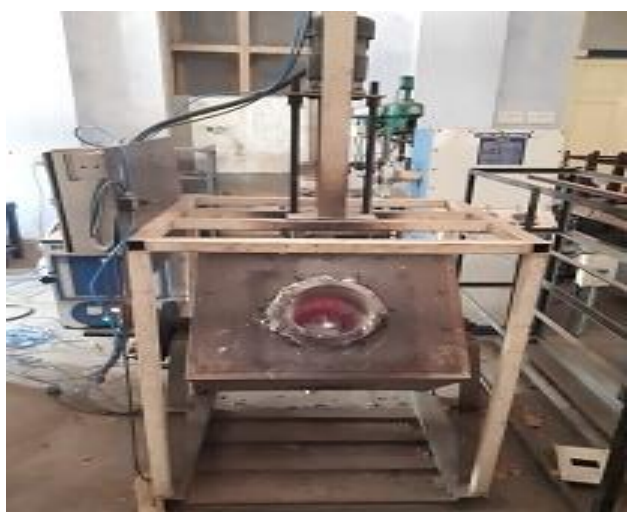

Fig 3 Stir Casting Apparatus.

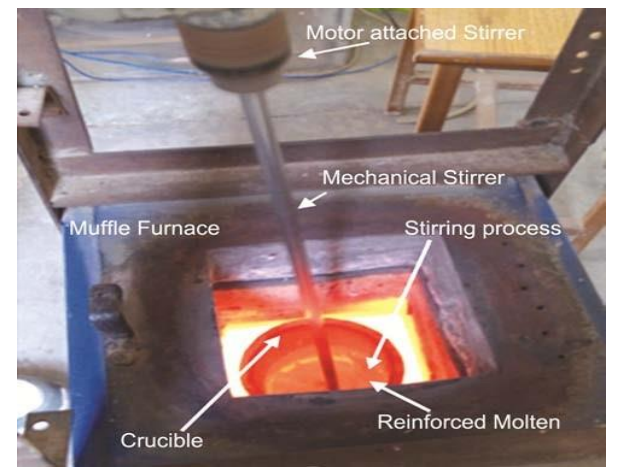

Fig 4 Stir Casting Process

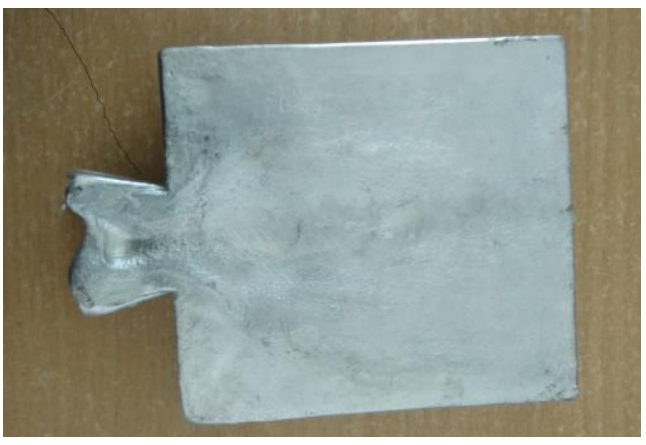

Fig 5. Al-B4C MMCs Specimen.

\section{RESULTS AND DISCUSSIONS}

Hardness Test Hardness is a diploma of the manner resistant stable depend is to diverse types of permanent form alternate at the same time as a compressive force is achieved. A few substances, which consist of steel, are extra difficult than others. Macroscopic hardness is generally characterized through strong intermolecular bonds; however the behavior of solid substances under force is complicated. Therefore, there are unique measurements of hardness like scratch hardness, indentation hardness, and rebound hardness. It's miles depending on viscosity, elastic stiffness, visco elasticity, pressure, strength, sturdiness, plasticity, and ductility. A Microvicker Robustness Tester tool used for the hardness dimension of composite material as shown if Fig 8. Hardness test come to be accomplished on the specimens of 3.5, 7.0 and $10.5 \%$ wt Al-B4C composites under a load of 0 .Five kg- $\mathrm{f}$ and 10 se are living time the usage of micro indenter of diamond in Table 6 and in Fig 6 \& 7.The not unusual hardness of $3.5,7.0$ and 10.5p.Cwt Al-B4C composites are discovered to be58,71and 54.6 HV0.5 respectively.

Table 6 Microvickers Hardness value of Al-B4C MMCs

\begin{tabular}{|c|c|c|c|}
\hline S.No & Samples & Hardness (HV0.5) & Average \\
\hline \multirow{3}{*}{1} & \multirow{3}{*}{ Al-3.5 \%B4C } & 59 & \multirow{3}{*}{58} \\
\hline & & 60 & \\
\hline & & 55 & \\
\hline \multirow{3}{*}{2} & \multirow{3}{*}{$\mathrm{Al}-7.0 \% \mathrm{~B} 4 \mathrm{C}$} & 72 & \multirow{3}{*}{71} \\
\hline & & 70 & \\
\hline & & 71 & \\
\hline 3 & Al-7.0 \%B4C & 55 & 54.6 \\
\hline
\end{tabular}



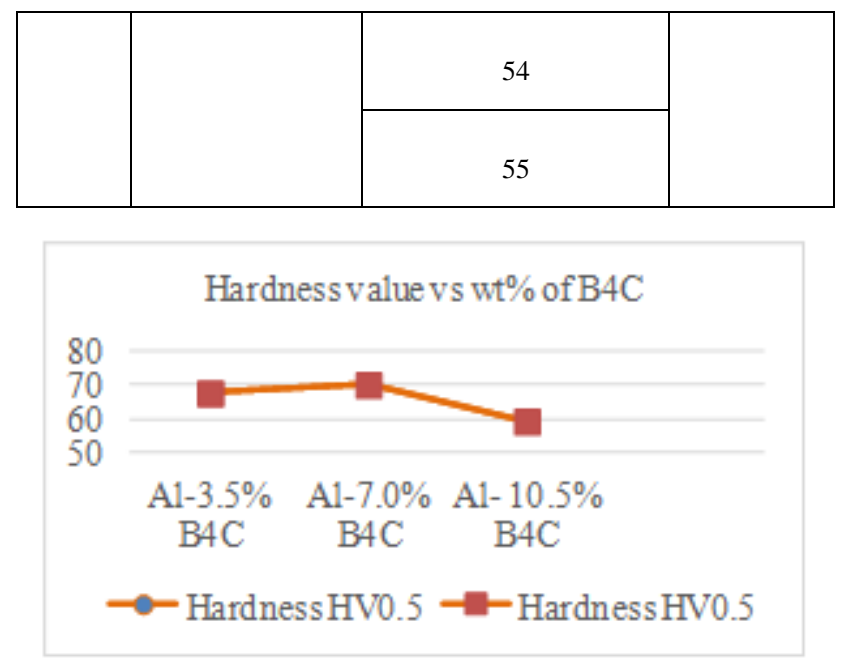

Fig 6: Shown the graph between Hardness value and percentage of $\mathrm{B} 4 \mathrm{C}$.

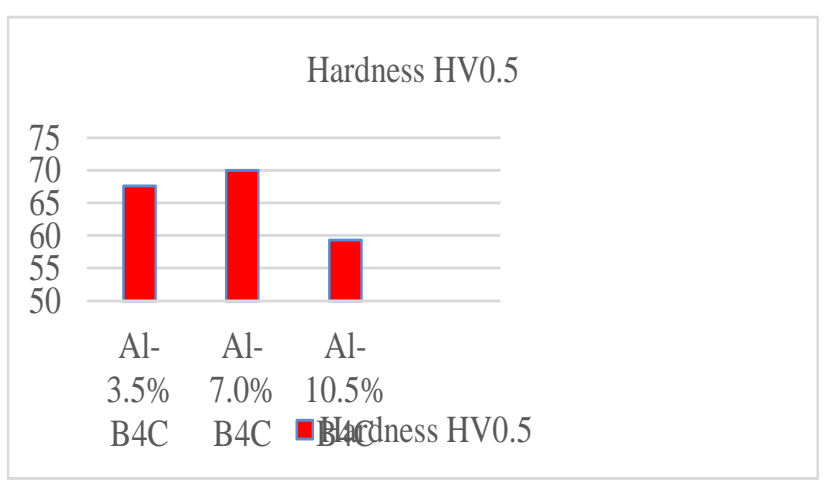

Fig 7: Hardness bar chart

Fig 7 suggests the bar chart diagram which representing the developments in growing hardness on increment of $\mathrm{B} 4 \mathrm{C}$ content.

The above end result suggests that boom of wt\% of B4C in Al-B4C metallic Matrix Composite leads to hardness development.

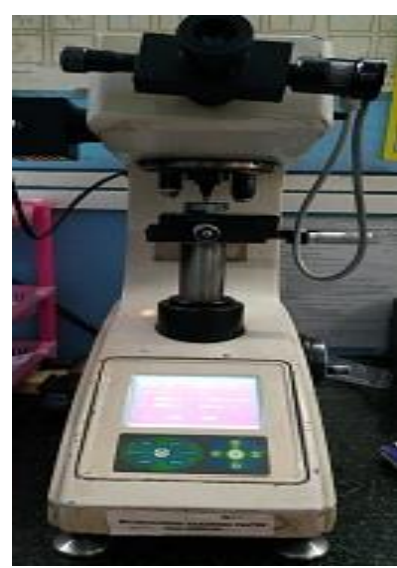

Fig 8.Microvickers Hardness Tester

\section{CONCLUSION}

The Al-B4C composite had been produced stir casting method with one-of-a-kind wt \% (three.5\%,7.Zero\% and 10.Five $\%$ ) of reinforcement and the microstructure and hardness are evaluated. From the look at the following end are derived.

* Production of Al-Boron Carbide composites turned into finished efficiently

* The microvicker' s hardness of Al-B4C MMCs became determined to be max (71 HV0.5) for the wt\% of 7.0 boron carbide.

\section{REFERENCES}

1. P. Auerkari, "Mechanical and Physical Properties of Engineering Alumina Ceramics," VTT Manufacturing Technology, Julkaisija-Utgivare Publisher, Finland, 1996.

2. D. Chandramohan, and K. Marimuthu, "A Review on Natural Fibers," International Journal of Research and Reviews in Applied Sciences, vol 8, No. 2, 2011, pp.194-206.

\section{AUTHORS PROFILE}

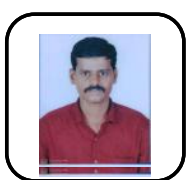

Sathiyaraj.S*, Assistant Professor Mechanica Department, AarupadaiVeedu Institute Of Technology, Vinayaka Mission's Research Foundation, Deemed To Be University. Having 8 years of experience. Life member in ISTE and ENFUSE.

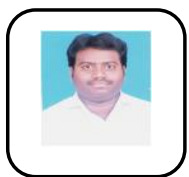

S. Kalyana kumar, Assistant Professor Mechanical Department, Aarupadai Veedu Institute of Technology, Vinayaka Mission's Research Foundation, Deemed To Be University. kalyanakumar@avit.ac.in.

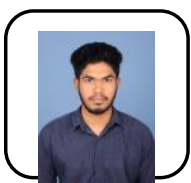

Mohammed Fayis, UG Student, Mechanica Department, Aarupadai Veedu Institute of Technology, Vinayaka Mission's Research Foundation, Deemed To Be University

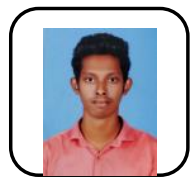

N. Ronald Jaison, UG Student, Mechanical Department, Aarupadai Veedu Institute of Technology, Vinayaka Mission's Research Foundation, Deemed To Be University

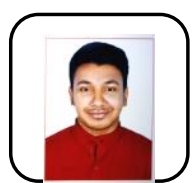

Rony Samraj ,UG Student, Mechanical Department, Aarupadai Veedu Institute of Technology, Vinayaka Mission's Research Foundation, Deemed To Be University

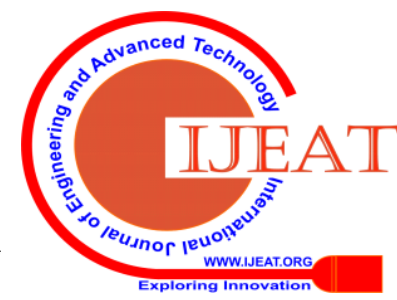

